\title{
Influence of Ionizing Irradiation on Magnetosensitive Transistor Structures
}

\author{
Ya.I. Lepikh*, M.A. Glauberman \\ Interdepartmental Scientific-Educational Physics and Technical Center of MES and NAS of Ukraine at the \\ Odesa I.I. Mechnikov National University, 2, Dvoryanskaya St., 65082 Odesa, Ukraine
}

(Received 21 March 2021; revised manuscript received 10 August 2021; published online 20 August 2021)

\begin{abstract}
The work is devoted to the study of the influence of ionizing radiation and temperature on the main magnetosensitive transistor structure (MTS) characteristics. MTS are widely used in various fields of science and technology, in particular, as magnetic field sensors, position and movement sensors of structural elements of various systems and etc. The characteristics of MTS and, accordingly, devices based on them may be unstable due to the influence of external factors. One of these factors is ionizing radiation. In this work, we investigated the effect of irradiation at the "Elektroniks" linear accelerator with fast electrons and at the "Gamma-25" MRS installation with $\gamma$-quanta on the MTP absolute sensitivity. MTS samples with different surface electrical resistance values were irradiated with different doses and intensities. The influence of heat treatment on MTS samples after their irradiation was also investigated. The dependences of the MTS sensitivity on various integral doses of electron irradiation and $\gamma$-quanta intensity are presented. The change in the MTS sensitivity dependence on the annealing temperature on the structure characteristics was established. The possibility of using the temperature effect to stabilize the MTS characteristics was investigated. The optimal range of MTS annealing temperature near $450{ }^{\circ} \mathrm{C}$ in air and the heating time, at which the defect formation process which could negatively affect the MTS characteristics does not occur in the semiconductor structure, and, accordingly, in devices based on them, were determined. It is shown that MTS heat treatment after irradiation with fast electrons and $\gamma$-quanta can be successfully used to stabilize the MTS characteristics.
\end{abstract}

Keywords: Magnetosensitive transistor structures, Ionizing irradiation, Annealing.

\section{INTRODUCTION}

To date, a significant number of works have been published, in particular [1-7], devoted to the investigation of formation peculiarities and study of the properties of radiation defects in semiconductors, especially in silicon, as the main material of modern semiconductor electronics, as well as in various semiconductor devices and integrated circuits. However, most of the works are not systematic and do not provide an unambiguous explanation of the influence mechanism of ionizing radiation on the semiconductor parameters from the standpoint of their magnetic sensitivity.

In addition, the problem of ensuring the stability of the characteristics of magnetically sensitive semiconductor structures and devices based on them is also important, in some cases it is determining in terms of their application.

\section{PROBLEM STATEMENT. OBJECT AND RESEARCH METHODS}

In this work, the tasks were set to study the effect of ionizing radiation on the characteristics of MTS and search for methods of their stabilization.

MTS is the main sensitive element of sensors for various functional purposes. Fig. 1 shows the basic types of bipolar magnetosensitive structures (BMSs).

Comparing the BMS properties, they can be considered as separate limiting cases of semiconductor magnetosensitive transistor structures (MTSs).

Magnetotransistors [5-7] are generally bipolar transistors, the design and operating mode of which are optimized to obtain the strongest dependence of the collector current on the induction of the external magnetic field. The minority carriers injected by the emitter $E$, while drifting (diffusing at $V=0$ ) in the $E_{0}$ direction, simultaneously diffuse to the collector $\mathrm{C}$, creating a collector current. The magnetic field, depending on its direction, deflects these carrier flows to or from the collector and thereby creates a signal as a change in this current. The specificity of the planar technology determines the MTS classification according to the injected carrier current direction in the magnetic field absence and according to the direction of the recorded magnetic induction component relative to the structure technological surface [8]

According to the first indication, MTSs are divided into vertical and horizontal, where the current direction is, respectively, perpendicular and parallel to the sample surface. According to the second - into MTSs with longitudinal and transverse magnetic axes (the recorded magnetic induction component is, respectively, parallel and perpendicular to this surface).

It is known that the parameters of any semiconductor material and structure are significantly affected by various types of ionizing radiation through, in particular, the defect formation mechanism.

In the manufacture and operation process, semiconductor devices are exposed to irradiation of various types: X-ray, gamma radiation, proton fluxes, electrons, neutrons, $\alpha$-particles, ions. The source of intense radiation is radioactive materials, nuclear reactors, protons and electrons in the Earth's radiation fields, solar and galactic cosmic radiation.

\footnotetext{
*ndl_lepikh@onu.edu.ua
} 

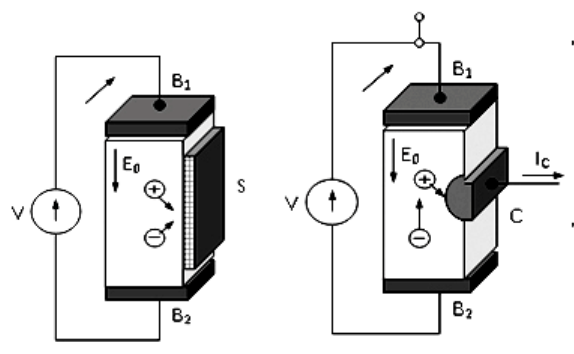

a)

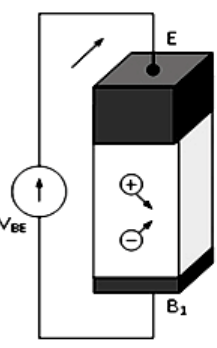

c)

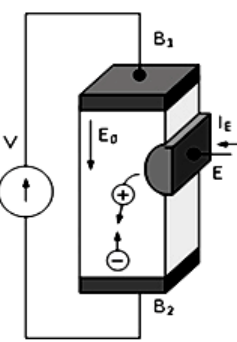

d) b)

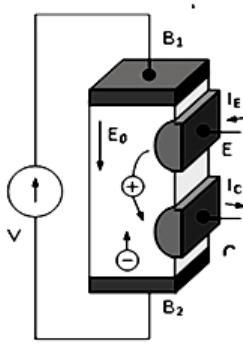

e)
Fig. 1 - BMS basic types: galvano-magneto-recombination structure (a), Longhini structure (b), magnetodiode (c), two-base magnetodiode (d), magnetotransistor (e)

The importance of radiation effects investigation is due to the fact that during such actions in the device base the formation of radiation defects (RDs) occurs, which affects its basic parameters.

Therefore, the study of RD influence plays a significant role in the development and creation of new semiconductor devices, and the study of the physical mechanism of their operation can lead to important conclusions about the influence of intrinsic structural defects on material parameters.

Radiation, interacting with a solid, causes ionization of the lattice atoms and displacement, thereby changing the structural and electrophysical properties of a material, which leads to changes in the semiconductor device characteristics. Structural disturbances primarily include the formation of primary RDs such as Frenkel pairs (vacancy and internodal atom) in the crystal lattice as a result of elastic impact of a moving particle with the atom nucleus or with an atom of matter; the formation of primary defects in the form of divacancies is also possible. Vacancies and knocked out atoms can move on a solid and lead to the formation of secondary defects when interacting with each other and with defects that exist before irradiation $(A$-, $E$-centers, divacancies, etc.).

The levels of $E_{c}-0.16 \mathrm{eV}, E_{c}-0.4 \mathrm{eV}, E_{v}+0.45 \mathrm{eV}$, $E_{v}+0.30 \mathrm{eV}$, and $E_{v}+0.01 \mathrm{eV}$ are introduced at the highest rate in silicon irradiated with different types of radiation. Basically, these levels determine the electrophysical properties of irradiated silicon, the main current carrier concentration, and the minority carrier lifetime. The charge carrier mobility may depend on the areas of disorder concentration.

DMTS samples, made by standard planar technology based on $n$-silicon with initial values of the surface electrical resistance $\rho$ equal to $150 \div 180 \mathrm{Ohm} \cdot \mathrm{cm}$ and $100 \mathrm{Ohm} \cdot \mathrm{cm}$, were irradiated with electrons with energies of $2.5 \mathrm{MeV}$ at room temperature with a variable integrated radiation dose from $10^{13}$ to $10^{16} \mathrm{el} / \mathrm{cm}^{2}$. Irradiation was performed on a linear accelerator "Electronics".

\section{INVESTIGATION RESULTS AND THEIR DISCUSSION}

The effect of irradiation on the absolute magnetic sensitivity $S A$ when irradiated with integral doses up to $3 \cdot 10^{13} \mathrm{el} / \mathrm{cm}^{2}$ was studied for samples with $\rho=150 \div 180 \mathrm{Ohm} \cdot \mathrm{cm}$. The change in sensitivity under these conditions was practically absent and was detected only under irradiation with doses $\Phi>3 \cdot 10^{13} \mathrm{el} / \mathrm{cm}^{2}$ as a monotonic decrease, which can be approximated by the dependence $S A \infty \exp (-K / \Phi), \quad K=2 \cdot 10^{16} \mathrm{el} / \mathrm{cm}^{2}$ (curve 1, Fig. 2). At doses above $3 \cdot 10^{13} \mathrm{el} / \mathrm{cm}^{2}$, there was a decrease in the diffusion length $l$ at the transistor base due to an increase in the concentration of RDs and the formation of areas of disorder.

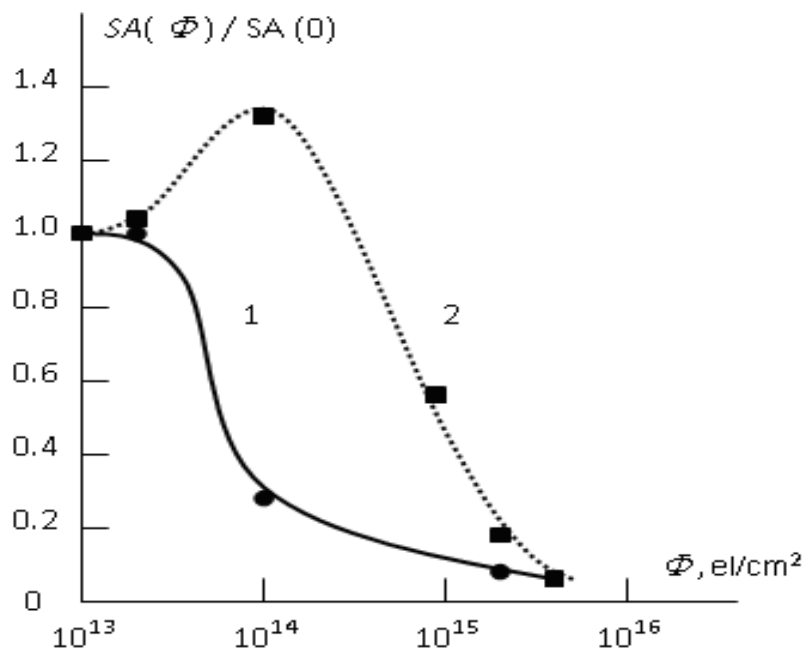

Fig. 2 - The DMTS absolute sensitivity dose dependence when irradiated with electrons: 1 - immediately after irradiation and 2 - after annealing

For samples with $\rho=100 \mathrm{Ohm} \cdot \mathrm{cm}$, the $S R$ dependence on the radiation dose was studied and an increase in this value was found (Fig. 3) when irradiated with integral doses from $10^{13}$ to $3 \cdot 10^{13} \mathrm{el} / \mathrm{cm}^{2}$. At doses over $3 \cdot 10^{13} \mathrm{el} / \mathrm{cm}^{2}$, a decrease in $S R$ was also observed.

After irradiation, DMTS were subjected to annealing, the results of which made it possible to judge the effect of RDs introduced into the DMTS structure on its magnetic sensitivity.

Isochronous annealing of DMTS samples irradiated with electrons was performed in the temperature range of $50 \div 400{ }^{\circ} \mathrm{C}$ with a temperature step of $50{ }^{\circ} \mathrm{C}$ with exposure at each temperature for $30 \mathrm{~min}$.

The $S A$ for DMTS samples annealed at $300^{\circ} \mathrm{C}$ with $\rho=150 \div 180 \mathrm{Ohm} \cdot \mathrm{cm}$ typically indicates the presence of a maximum corresponding to $\Phi \approx 10^{14} \mathrm{el} / \mathrm{cm}^{2}$ (curve 2, Fig. 2). Maximum conservation at a dose of $3.10 \mathrm{el} / \mathrm{cm}^{2}$ is typical for $S R$ structures with $\rho=100 \mathrm{Ohm} \cdot \mathrm{cm}$ (see Fig. 3). From Fig. 3 it is also seen a decrease in the $S R$ scatter values from sample to sample.

When the samples are irradiated with an electron dose of $3 \cdot 10^{13} \mathrm{el} / \mathrm{cm}^{2}$, the Hall mobility increases approximately 3.3 times - from $3 \cdot 10^{3}$ to $10^{4} \mathrm{~cm}^{2} /(\mathrm{V} \cdot \mathrm{s})$, which is explained by a decrease in the concentration of 
impurity scattering centers under the action of low doses of electron irradiation. It turns out that during scattering of inhomogeneities, the formation of $\mathrm{RDs}$ of small concentration and the presence of ionization are of great importance.

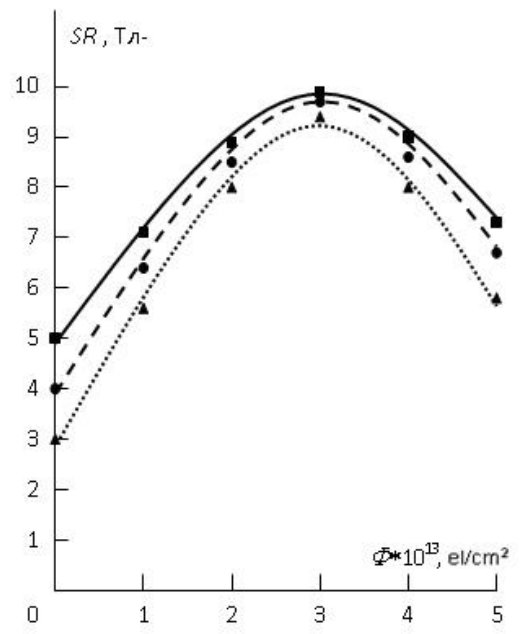

Fig. 3 - Dose dependence of the conversion efficiency for three samples from the DMTS experimental batch: $\boldsymbol{\Delta}-10^{13} \mathrm{el} / \mathrm{cm}^{2}$, - $-3 \cdot 10^{13} \mathrm{el} / \mathrm{cm}^{2}, \mathbf{\square}-5 \cdot 10^{13} \mathrm{el} / \mathrm{cm}^{2}$

Probably, the main role in the scattering of inhomogeneities is played by the diffuse mechanism. At doses above $3 \cdot 10^{13} \mathrm{el} / \mathrm{cm}^{2}$ for DMTS with initial $\rho=100 \mathrm{Ohm} \cdot \mathrm{cm}$, the mobility begins to decrease due to the contribution to the scattering process of an increased concentration of RDs, as well as the disorder areas. The sample annealing provides stability, which is determined by the low concentration of RDs and the presence of ionization effects. Since $S A \infty S R \infty \mu_{m n}^{*}, \mu_{m j}^{*}$, the corresponding magnetic sensitivity dependence on the radiation dose is observed. The appearance of the maximum magnetic sensitivity is associated with an increase in the lifetime of injected minority charge carriers after annealing, consistent with nonequilibrium lifting and various transitions of structural disorder (e.g., those that occurred during sample production) into drains or their mutual annihilation [9].

Further investigations have shown that for magnetically sensitive transistors there is a minimum energy value of $4.5 \mathrm{MeV}$, below which electrons have a lesser effect on the transistor parameters sensitive to the magnetic field. The use of energy greater than $10 \mathrm{MeV}$ is technologically impractical. The annealing temperature of $450{ }^{\circ} \mathrm{C}$ was chosen for the reason that at lower temperatures the annealing is inefficient, and at temperatures above $490^{\circ} \mathrm{C}$ defects are introduced into the semiconductor structure, which worsens the $p$ - $n$ junction parameters. When the annealing duration is less than $2 \mathrm{~h}$, the increase in magnetic sensitivity decreases. An increase in the annealing duration for more than $3 \mathrm{~h}$ unjustifiably increases the technological cycle duration and energy losses.

The effect of irradiation with $\gamma$-quanta ${ }^{60} \mathrm{Co}$ on the DMTS initial characteristics was also studied. Irradiation with $\gamma$-quanta ${ }^{60} \mathrm{Co}$ was performed on an MPX
"Gamma-25" installation with an intensity of $299 \mathrm{R} / \mathrm{s}$ with a change in the integrated radiation dose. By the type of defect formation, $\gamma$-quanta act similarly to fast electrons. For most DMTS, the current dose dependence of the magnetic sensitivity (in the range of the studied doses) has two characteristic areas: the region, in which the magnetic sensitivity does not depend on the radiation dose: $10^{5}<\Phi<10^{6} \mathrm{rad}$; and the region of a monotonic drop of the magnetic sensitivity: $\Phi>10^{6} \mathrm{rad}$.

The region of the current monotonic reduction of the magnetic sensitivity $10^{6}<\Phi<5 \cdot 10^{7} \mathrm{rad}$ can be described by the expression $S A=S A(0) \cdot(1-K T \Phi)$, where $K T=(1 \div 3) \cdot 10^{-8} \mathrm{rad}^{-1}$. Here, the dose dependence is also connected with a role of the formation of surface and volume defects at irradiation.

Annealing of samples irradiated with $\gamma$-quanta was performed in the temperature range of $50 \div 300{ }^{\circ} \mathrm{C}$ with a step of $25^{\circ} \mathrm{C}$. Fig. 4 shows the dependences of the $S A(\Phi) / S A(0)$ ratio on the radiation dose of $\gamma$-quanta for DMTS samples made on $n$-Si basis $(\rho=150 \div 180$ $\mathrm{Ohm} \cdot \mathrm{cm}$ ) after irradiation (curve 1) and annealed after irradiation at $120^{\circ} \mathrm{C}$ for $30 \mathrm{~min}$ (curve 2).

It is typical that for annealed samples the maximum occurs on the dependence of the magnetic sensitivity. Curve 3 in Fig. 4 describes the known dose dependence of the current magnetic sensitivity of КД-303 silicon magnetic diode. Comparison of $\gamma$-quanta ${ }^{60} \mathrm{Co}$ effect on DMTS and КД-303 shows a sharper decrease in the magnetic sensitivity of magnetodiodes with an increase in the irradiation dose.

Increasing the magnetic sensitivity and improving the reproducibility of DMTS parameters allow to offer one of the simplest methods to improve the DMTS manufacturing technology, which consists in irradiating them before encapsulation with an electron flux with $\Phi=10^{13} \div 3 \cdot 10^{13} \mathrm{el} / \mathrm{cm}^{2}$ with energy of $4 \div 10 \mathrm{MeV}$ and subsequent annealing at $200 \div 250{ }^{\circ} \mathrm{C}$ for $2 \div 3 \mathrm{~h}$.

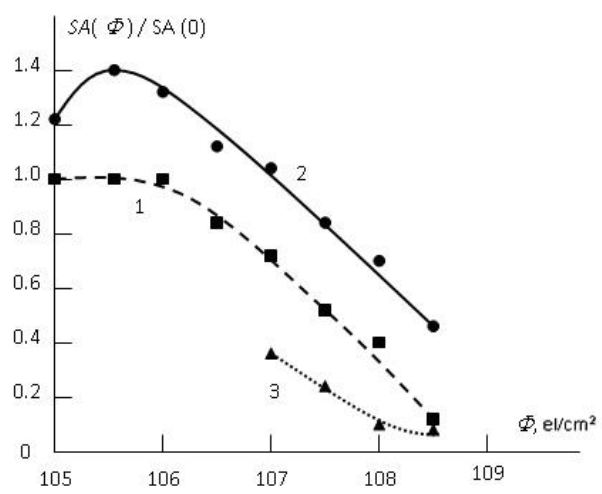

Fig. 4 - Dose dependence of the DMTS absolute sensitivity when irradiated with $\gamma$-quanta ${ }^{60} \mathrm{Co}: 1$-immediately after irradiation; 2 - after annealing; 3 - for КД-303 magnetodiode

\section{CONCLUSIONS}

The effect of ionizing radiation on the physical parameters of semiconductors leads to changes in the MTS basic parameters and, in particular, to a decrease in their magnetic sensitivity at absorbed doses greater than $10^{15} \mathrm{el} / \mathrm{cm}^{2}\left(10^{6} \mathrm{rad}\right)$ due to surface and bulk defects. 


\section{ACKNOWLEDGEMENTS}

The authors are thankful to Prof. Vikulin I.M. from the Odesa National Academy of Telecommunications for research results and useful discussions.

\title{
REFERENCES
}

1. Ya.I. Lepikh, N.Ya. Rakhmanov, G.V. Prokhorov A.K. Gnap, Fotoelektronika 12, 119 (2003) [In Russian].

2. A.V. Kosikhin, S.B. Baklanov, S.G. Novikov, N.T. Gurin, Techn. Phys. 77 No 1121 (2007) [In Russian].

3. V.A. Saakyan, Izvestiya NAN Armenii, Fizika 43 No 5, 348 (2008) [In Russian].

4. Ya.I. Lepikh, Yu.O. Hordiyenko, S.V. Dzyadevych, A.O. Druzhynyn, A.A. Yevtukh, S.V. Lyenkov V.H. Melnyk, V.O. Romanov, Stvorennya mikroelektronnykh datchykiv novoho pokolinnya dlya intelektualnykh system (Red. Ya.I. Lepikh), (Odesa: Astroprynt: 2010) [In Ukrainian].

5. B.P. Koman, Sensor Electronics and Microsystem Technologies (SEMST) 3(9) No 1, 95 (2012).

6. O. Kulinich, M. Glauberman, V. Yegorov, Magnito-tranzistory: fizika, modelirovaniye, primeneniye (LAP LAMBERT: Academic Publishing GmbH \& Co.KG: 2012).

7. O. Fadeeva, Visnyk of Pridneprovsk State Academy of Civil Engineering and Architecture., № 6, 13 (Dnipro: PSACEA, 2013).

8. S. S. Suvanam, Radiation Hardness of 4H-SiC Devices and Circuits, Doctoral Thesisin Information and Communication Technology, School of Information and Communication Technology (Stockholm: KTH Royal Institute of Technology, Sweden: 2017)

9. M.A. Glauberman, Ya.I. Lepikh, International Research and Practice Conference: Nanotechnology and Nanomaterials (NANO-2020) 510 (Lviv: 2020).

\section{Вплив іонізуючого опромінення на характеристики магніточутливих транзисторних структур}

\author{
Я.І. Лепіх, М.А. Глауберман
}

Одеський національний університет ілені I.І. Мечникова, вул. Дворянська, 2, 65082 Одеса, Україна

Робота присвячена дослідженню впливу іонізуючого опромінення і температури на основні характеристики магніточутливих транзисторних структур (МТC). МТС широко використовуються у різних сферах науки і техніки, зокрема, як сенсори магнітного поля, сенсори положення та переміщення елементів конструкцій різних систем тощо. Характеристики MTC i, відповідно, пристроїв на їх основі можуть бути нестабільними через вплив зовнішніх факторів. Одним з таких факторів е іонізуюче випромінювання. В даній роботі досліджувався вплив опромінення на лінійному прискорювачі «Електроніка» швидкими електронами і на установці МРX «Гама-25» $\gamma$-квантами на абсолютну чутливість MTP. Опромінювалися зразки МТС з різними значеннями поверхневого електричного опору різними дозами та інтенсивностями. Досліджувався також вплив термообробки зразків МТC після їх опромінення. Наводяться залежності чутливості МТС від різних інтегральних доз опромінення електронами та інтенсивності $\gamma$-квантів. Встановлена зміна залежності чутливості МТС від впливу температури на характеристики структур. Досліджено можливість використати вплив температури для стабілізаціі характеристик MTC. Визначено оптимальний діапазон температури відпалу МТC поблизу $450{ }^{\circ} \mathrm{C}$ у повітрі та час нагріву, за яких у структурі напівпровідника не відбуваеться процес дефектоутворення, що могло б негативно вплинути на характеристики MTC i, відповідно, на пристрої на їх основі. Показано, що термообробка МТC після опромінення швидкими електронами та $\gamma$-квантами може з успіхом використовуватися для стабілізації характеристик МТС.

Ключові слова: Магніточутливі транзисторні структури, Іонізуюче опромінення, Відпал. 